\title{
Modulation of Cellular Response to Arsenic Trioxide Toxicity by Resveratrol
}

\author{
Bodhisattwa Mondal, ${ }^{\dagger}$ Hongxia Chen, ${ }^{\dagger}$ Weihua Wen, ${ }^{\dagger}$ Ercole L. Cavalieri, ${ }^{\dagger}$ Eleanor G. Rogan, ${ }^{\dagger,}$ \\ and Muhammad Zahid*,†
}

${ }^{\dagger}$ Department of Environmental, Agricultural, and Occupational Health, College of Public Health, and the Eppley Institute for
Research in Cancer and Allied Diseases, University of Nebraska Medical Center, Omaha, Nebraska 68198, United States

Supporting Information

ABSTRACT: Arsenic trioxide $\left(\mathrm{As}_{2} \mathrm{O}_{3}\right)$ is an environmental carcinogen and a putative endocrine disruptor. Resveratrol has been shown to reverse $\mathrm{As}_{2} \mathrm{O}_{3}$-induced oxidative damage. In immortalized but nontransformed estrogen receptor $\alpha$ negative human breast cells (MCF10A), we observed that 25 $\mu \mathrm{M}$ resveratrol ameliorated $\mathrm{As}_{2} \mathrm{O}_{3}$-induced cytotoxicity. $\mathrm{As}_{2} \mathrm{O}_{3}$, in the presence or absence of $25 \mu \mathrm{M}$ resveratrol, induced quinone reductase $(\mathrm{NAD}(\mathrm{P}) \mathrm{H}$ quinone dehydrogenase 1$)$, via the induction of NFE2-related factor $2 . \mathrm{As}_{2} \mathrm{O}_{3}$ caused a repression of cytochrome $\mathrm{P} 450$ (CYP)1B1, but the addition of $25 \mu \mathrm{M}$ resveratrol rescued the expression of cytochrome P450 1B1 and kept it at a constant level. Therefore, $25 \mu \mathrm{M}$ resveratrol can modulate the effects of $\mathrm{As}_{2} \mathrm{O}_{3}$ on enzymes involved in estrogen metabolism.

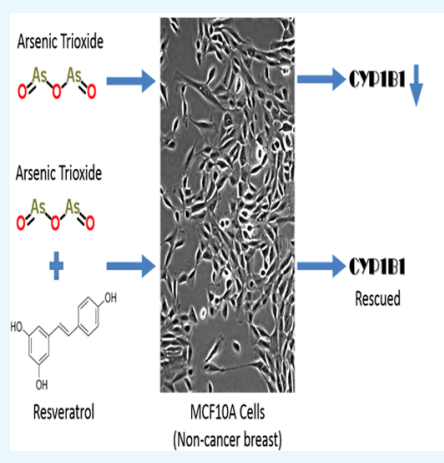

Modulation of Cellular Response to Arsenic Trioxide Toxicity by Resveratrol

Bodhisattwa Mondal, Hongxia Chen, Weihua Wen, Ercole L. Cavalieri, Eleanor G. Rogan, and Muhammad Zahid

\section{INTRODUCTION}

Arsenic is the 20th most abundant element in the earth's crust, and trivalent arsenic trioxide $\left(\mathrm{As}_{2} \mathrm{O}_{3}\right)$ contaminates groundwater in many places, leading to arsenic poisoning or arsenicosis. ${ }^{1}$ Arsenic and inorganic arsenic compounds have been classified as IARC Group 1 carcinogens, ${ }^{2}$ with lung, bladder, kidney, and liver as the predominant targets. At the same time, $\mathrm{As}_{2} \mathrm{O}_{3}$ (Trisenox or arsenic trioxide) is being used as a chemotherapy drug against acute promyelocytic leukemia (APL), where it selectively kills the leukemic cells but allows the proper development of regular blood cells. ${ }^{3}$ Interestingly, arsenic has long been implicated in endocrine disruption. Target genes for glucocorticoids, androgens, mineralocorticoids, and progestin receptors have also been reported to be regulated by inorganic arsenic in a biphasic dose-response fashion. ${ }^{4}$ To address such documented carcinogenicity and putative endocrine disruption, the U.S. Environmental Protection Agency has set the maximum contaminant level for $\mathrm{As}_{2} \mathrm{O}_{3}$ at 10 ppb. ${ }^{5}$

The principal pathways implicated in $\mathrm{As}_{2} \mathrm{O}_{3}$ toxicity result from reactive oxygen species, oxidative DNA damage, and induction of apoptosis. Resveratrol, a well-known dietary stilbene, has been shown to protect normal human bronchial epithelial cells from $\mathrm{As}_{2} \mathrm{O}_{3}$ toxicity by maintaining glutathione homeostasis. ${ }^{6}$ Cardiotoxicity, a major side effect of using $\mathrm{As}_{2} \mathrm{O}_{3}$ for APL, could be ameliorated in Wistar rats by resveratrol, via the maintenance of a balanced expression of the NFE2-related factor 2 (Nrf2)-heme oxygenase (HO) 1 pathway, and by promoting arsenic efflux from cells. ${ }^{7}$ Employing similar mechanisms, resveratrol has been reported to protect from $\mathrm{As}_{2} \mathrm{O}_{3}$-induced nephrotoxicity in male Wistar rats ${ }^{8}$ and from hepatotoxicity in Chinese Dragon-Li cats. ${ }^{9}$ Finally, research by at least one group has demonstrated the ability of inorganic arsenic to promote carcinogenesis via a nonestrogen receptor (ER)-mediated pathway: chronic exposure (18 weeks) to environmentally relevant $0.5 \mu \mathrm{M}$ arsenite promoted cancer cell phenotypes in human prostate epithelial stem/progenitor cells (WPE-stem $)^{10}$ and in their isogenic parental RWPE-1 cells (30 weeks). ${ }^{11}$ Chronic exposure ( 24 weeks) to low-level arsenite $(500 \mathrm{nM})$ has also been reported to do the same thing in human breast epithelial cells (MCF10A) via the overexpression of aromatase. ${ }^{12}$ To the best of our knowledge, no studies have explored any protective role of resveratrol in $\mathrm{As}_{2} \mathrm{O}_{3}$-induced carcinogenesis via non-ER-mediated pathways.

Estrogens have been implicated in the development of a variety of cancers. Several types of evidence suggest the role of estrogen in tumor development in an ER knock-out transgenic mouse model of breast cancer, ${ }^{13}$ as well as in the transformation of ER $\alpha$-negative breast epithelial cells (MCF10F). ${ }^{14}$ To explain such receptor-independent pathways for cancer initiation, it has been hypothesized that the metabolism of estrogens/androgens generates catechol quinones that can react with DNA, leading to the formation of apurinic sites and mutations, to initiate oncogenic transformation. ${ }^{15}$ In high-risk

Received: November 5, 2017

Accepted: May 10, 2018

Published: May 21, 2018 
A

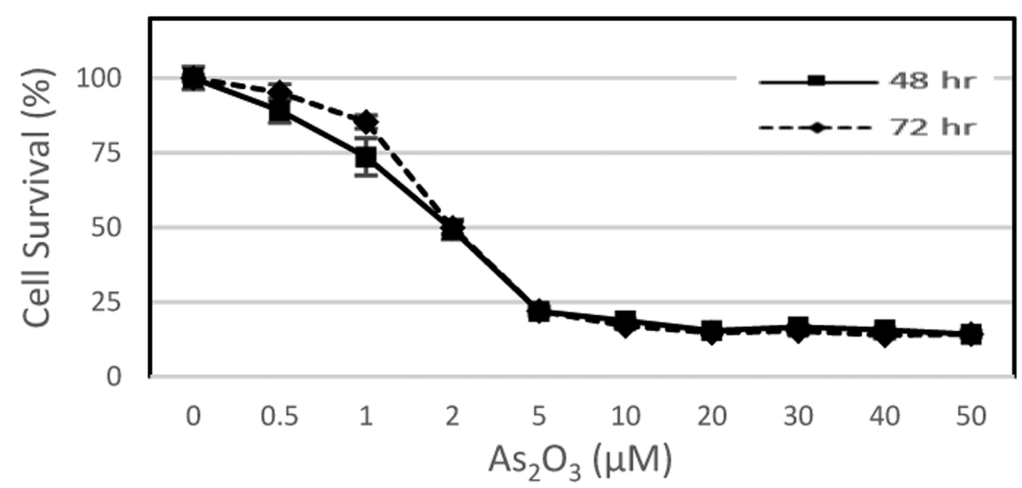

B
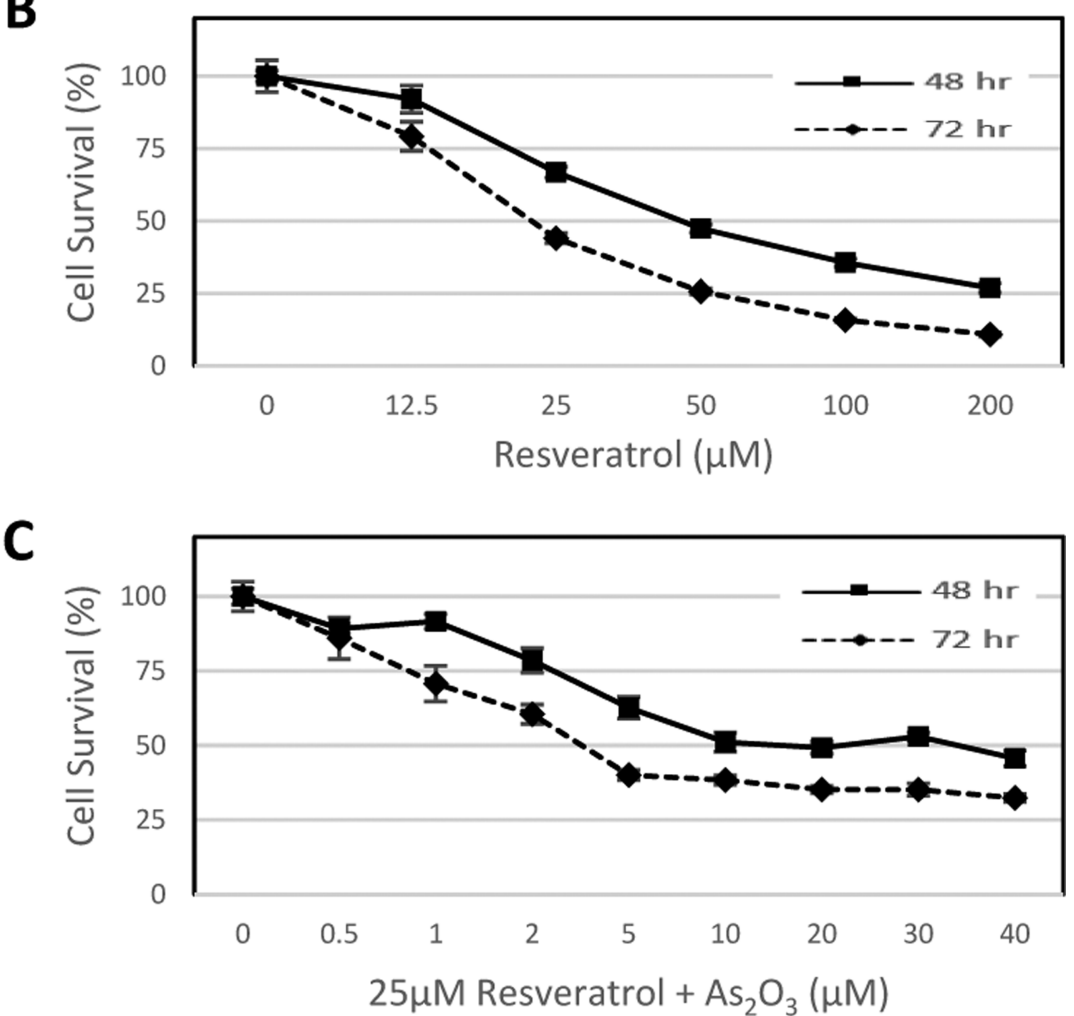

Figure 1. Viability of MCF10A cells treated with $\mathrm{As}_{2} \mathrm{O}_{3}$ with and without resveratrol. (A) Arsenic trioxide $\left(\mathrm{As}_{2} \mathrm{O}_{3}\right)$ alone. (B) Resveratrol alone. (C) Arsenic trioxide $\left(\mathrm{As}_{2} \mathrm{O}_{3}\right)+25 \mu \mathrm{M}$ resveratrol. Data are presented as mean \pm standard error of the mean cell survival (\%) from six independent experiments $(n=6)$.

groups and cancer patients (women: breast, ovarian, and thyroid; men: prostate and non-Hodgkin lymphoma), an imbalance in estrogen metabolism stems from irregular expression patterns of one or more of the four key estrogenmetabolizing enzymes: cytochrome P450 19 or aromatase, cytochrome P450 1B1 (CYP1B1), catechol-O-methyltransferase, and quinone reductase $(\mathrm{NAD}(\mathrm{P}) \mathrm{H}$ quinone dehydrogenase 1 (NQO1)). ${ }^{15}$ Certain naturally occurring or synthetic compounds have the ability to alter the expression of some of these enzymes; for example, 2,3,7,8-tetrachlorodibenzo- $p$-dioxin (TCDD) can induce CYP1B1, whereas resveratrol antagonizes this effect. At the same time, resveratrol can induce NQO1. ${ }^{15}$ Our laboratory has shown that preincubation with $25 \mu \mathrm{M}$ resveratrol for $48 \mathrm{~h}$ significantly lowered the production of estrogen-DNA adduct formation in $\mathrm{ER} \alpha$-negative human breast epithelial MCF10F cells. ${ }^{16}$ Therefore, in this study, the effects of $\mathrm{As}_{2} \mathrm{O}_{3}$ on the expression levels of key estrogen-metabolizing enzymes (NQO1 and CYP1B1), and on the signaling molecule
Nrf2, were studied in the presence or absence of $25 \mu \mathrm{M}$ resveratrol in immortalized but nontransformed ER $\alpha$-negative human breast epithelial cells (MCF10A).

\section{RESULTS AND DISCUSSION}

$\mathrm{As}_{2} \mathrm{O}_{3}$ exhibited cytotoxicity at both 48 and $72 \mathrm{~h}$, with an $\mathrm{IC}_{50}$ at $1.45 \mu \mathrm{M}$ for $48 \mathrm{~h}$ treatment (Figure $1 \mathrm{~A}$ ), which is an environmentally significant exposure. However, the presence of resveratrol, which also has some cytotoxicity (Figure 1B) at 25 $\mu \mathrm{M}$, reduced this cytotoxicity by shifting the survival curves to the right. The $\mathrm{IC}_{50}$ for the combined $48 \mathrm{~h} \mathrm{As}_{2} \mathrm{O}_{3}$ and resveratrol treatment was $28.69 \mu \mathrm{M}$. The rightward shift in the survival curve was lesser for $72 \mathrm{~h}$ treatment compared to that for $48 \mathrm{~h}$ treatment (Figure 1C). This indicates that the rescue effect from resveratrol is more pronounced at $48 \mathrm{~h}$.

$\mathrm{As}_{2} \mathrm{O}_{3}$, with or without $25 \mu \mathrm{M}$ resveratrol, induced the enzyme NQO1 in a dose-dependent manner, but no additive or synergistic effects were observed (Figure 2A,B). Resveratrol has 

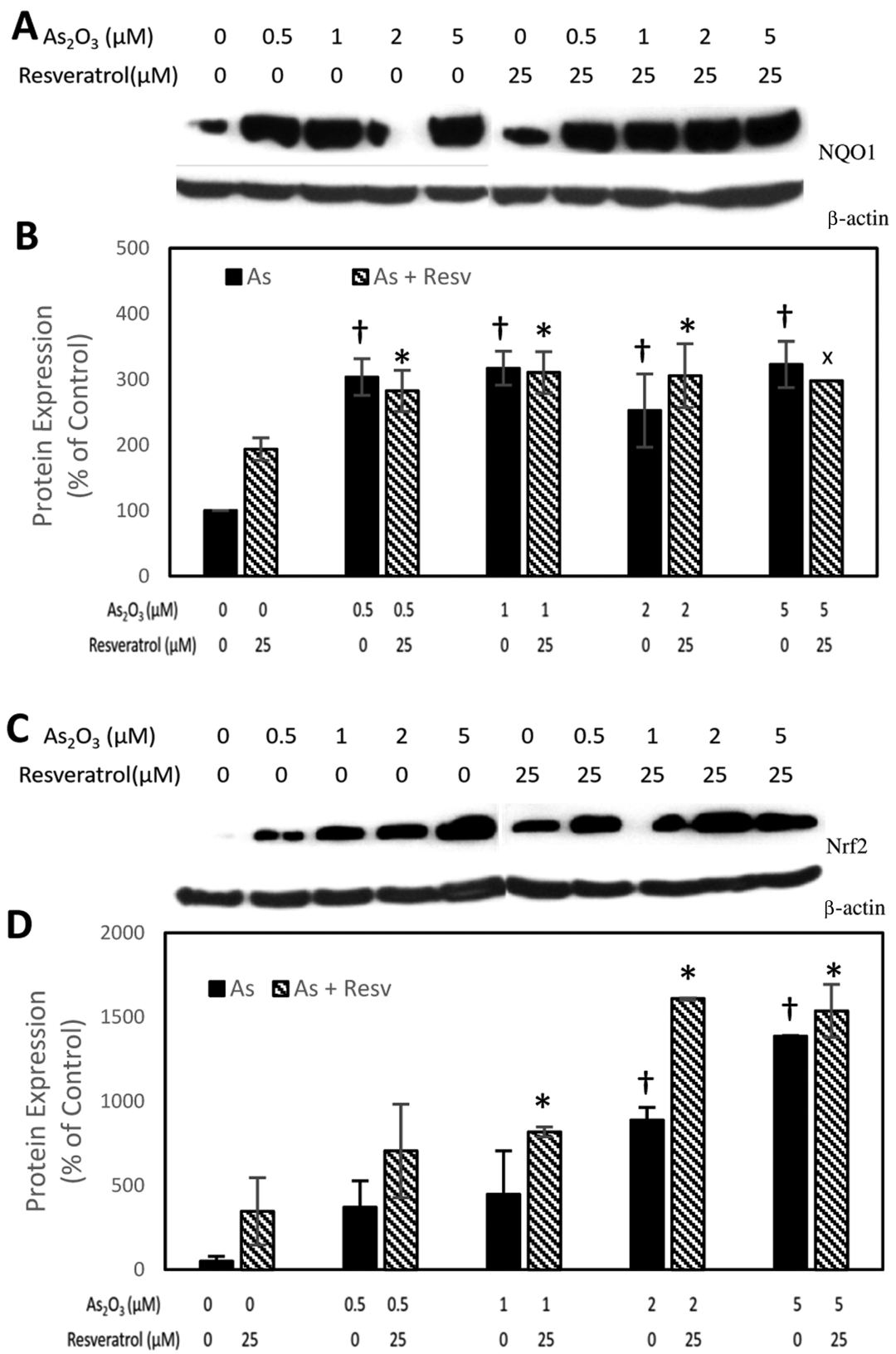

Figure 2. Induction of NQO1 (A, B) and Nrf2 (C, D) by $\mathrm{As}_{2} \mathrm{O}_{3}$ with and without resveratrol. (A, C) Representative images. (B, D) Quantitative data. Data are presented as mean \pm standard error of the mean protein expression (\%) from three independent experiments $(n=3)$, $X=$ mean of two experiments. A $\dagger$ indicates significant difference $(p<0.05)$ between $\mathrm{As}_{2} \mathrm{O}_{3}$ treatment groups and control, whereas an * indicates significant difference $(p<0.05)$ between $\mathrm{As}_{2} \mathrm{O}_{3}$ treatment groups and control in the resveratrol group.

been shown to act via the signaling molecule Nrf2, and NQO1 has been implicated as a downstream gene of Nrf2. ${ }^{17}$ This prompted us to study the effect of $\mathrm{As}_{2} \mathrm{O}_{3}$ on the expression level of $\mathrm{Nrf} 2 . \mathrm{As}_{2} \mathrm{O}_{3}$, in both the presence and absence of 25 $\mu \mathrm{M}$ resveratrol, induced $\mathrm{Nrf} 2$ in a dose-dependent fashion, but again no additive or synergistic effects were observed (Figure $2 \mathrm{C}, \mathrm{D})$. Our finding is in accordance with a study in mouse hepatoma cell line hepalc1c7, in which arsenic was shown to induce Nrf2 protein in a dose-dependent fashion, leading to a robust induction of NQO1. ${ }^{18}$ Furthermore, in MCF10A cells the extent of induction was much greater for Nrf2 compared to that for NQO1, but this may stem from the fact that resting cells have a very low-level basal expression of Nrf2 $\left(t_{1 / 2}=10-\right.$ $20 \mathrm{~min}) .{ }^{19}$ Similarly, disproportionate induction of NQO1 and $\mathrm{Nrf} 2$ by $\mathrm{As}_{2} \mathrm{O}_{3}$ has been reported in male Kunming mouse testis in both the presence and absence of antioxidants such as lutein. ${ }^{20}$

CYP1B1 is another key estrogen-metabolizing enzyme that is overexpressed in a variety of cancers, including breast cancer, and is subject to regulation through both hormonal and a putative aryl hydrocarbon receptor (AhR) pathways; the latter can be modulated by resveratrol. ${ }^{21}$ Previous studies on the male $\mathrm{C} 57 \mathrm{Bl} / 6$ mouse heart have reported that $12.5 \mathrm{mg} / \mathrm{kg}$ As(III) induces CYP1B1 mRNA levels by $150 \%{ }^{22}$ We observed, however, that $\mathrm{As}_{2} \mathrm{O}_{3}$ treatment $(0.5-5 \mu \mathrm{M})$ of human breast epithelial MCF10A cells caused a repression of CYP1B1 protein in a dose-dependent manner. Resveratrol was earlier shown to downregulate TCDD-induced CYP1B1 expression in MCF10F cells. ${ }^{23}$ Interestingly, the addition of $25 \mu \mathrm{M}$ resveratrol rescued $\mathrm{As}_{2} \mathrm{O}_{3}$-suppressed CYP1B1 expression and 


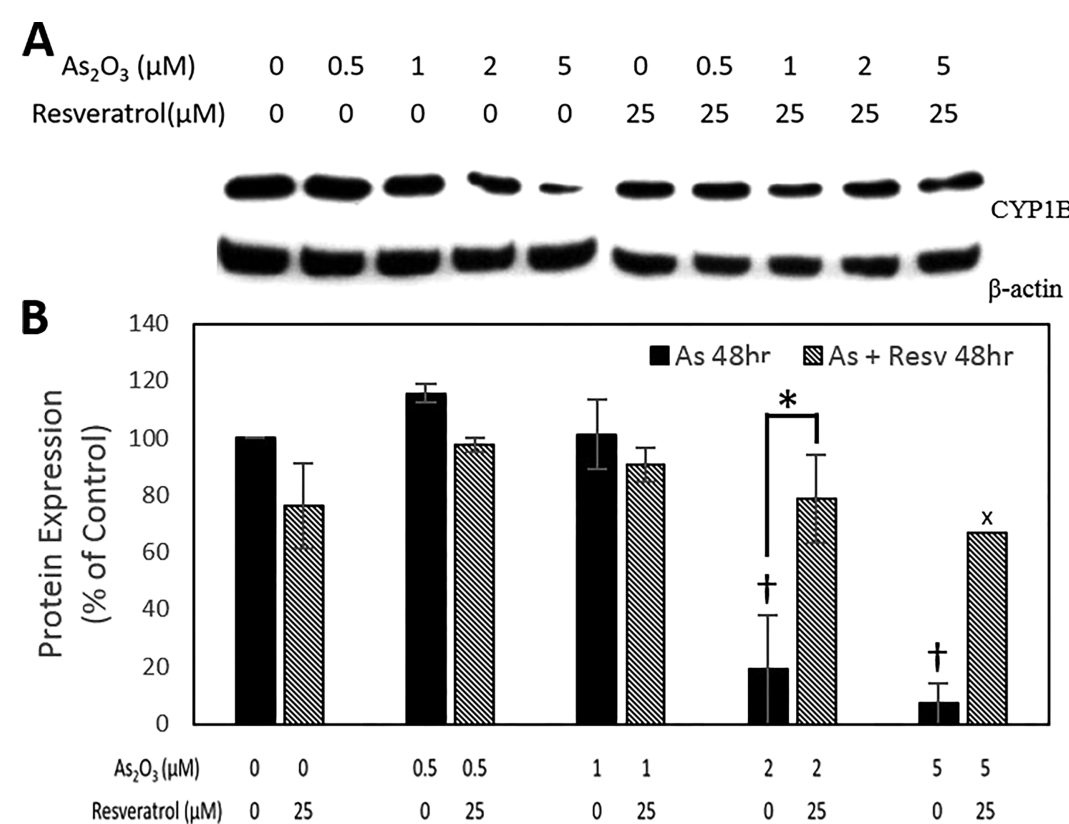

Figure 3. Repression of CYP1B1 by $\mathrm{As}_{2} \mathrm{O}_{3}$ with and without resveratrol. (A) Representative image. (B) Quantitative data. Data are presented as mean \pm standard error of the mean protein expression (\%) from three independent experiments $(n=3), X=$ mean of two experiments. A $\dagger$ indicates significant difference $(p<0.05)$ between $\mathrm{As}_{2} \mathrm{O}_{3}$ treatment groups and control, whereas an $*$ indicates significant difference $(p<0.05)$ between one particular $\mathrm{As}_{2} \mathrm{O}_{3}$ treatment with the inclusion or exclusion of resveratrol.

kept it at a nearly constant level (Figure 3A,B). To confirm this interesting observation, the expression of CYP1B1 enzyme was further studied simultaneously in three different nontransformed cell lines derived from human breast epithelia, namely MCF10A, MCF10F, and MCF12F cells. In this study, the cells were also treated with a higher dose of $7.5 \mu \mathrm{M} \mathrm{As} \mathrm{O}_{2}$. The repressive effect of $\mathrm{As}_{2} \mathrm{O}_{3}$ on CYP1B1 expression was less pronounced in MCF10F cells, leaving little room for resveratrol to exert any rescue effect (Supporting Information, Figure $\mathrm{S} 1 \mathrm{~B})$. Furthermore, such repressive effect of $\mathrm{As}_{2} \mathrm{O}_{3}$ on CYP1B1 expression was altogether absent in MCF12F cells (Supporting Information, Figure S1C). Collectively, these results suggest different degrees of modulatory effects of $\mathrm{As}_{2} \mathrm{O}_{3}$. One possibility is its differential cytotoxicity, as we have observed between MCF10A and MCF12F cells ( $\mathrm{IC}_{50}$ value for MCF10A is $1.45 \mu \mathrm{M}$ for $48 \mathrm{~h}$ treatment, whereas the same for MCF12F is $11.65 \mu \mathrm{M}$; Figure 1A vs Supporting Information Figure S2). $\mathrm{As}_{2} \mathrm{O}_{3}$ is not considered a ligand for $\mathrm{AhR}$; therefore, the observed effects of $\mathrm{As}_{2} \mathrm{O}_{3}$ might be mediated through a hormonal pathway.

Conclusions. In the present study involving nontransformed breast epithelial MCF10A cells, $25 \mu \mathrm{M}$ resveratrol was shown to ameliorate $\mathrm{As}_{2} \mathrm{O}_{3}$-induced cytotoxicity, with the beneficial effect being more prominent after $48 \mathrm{~h}$ treatment. As expected, both $\mathrm{As}_{2} \mathrm{O}_{3}$ and resveratrol induced the expression of the catechol quinone-quenching enzyme NQO1, possibly via the induction of the signaling protein Nrf2. To the best of our knowledge, however, this is the first time resveratrol has been shown to rescue $\mathrm{As}_{2} \mathrm{O}_{3}$-suppressed CYP1B1 expression back to the baseline levels. Collectively, these results suggest that 25 $\mu \mathrm{M}$ resveratrol has the ability to modulate the effects of $\mathrm{As}_{2} \mathrm{O}_{3}$ on the expression of estrogen-metabolizing enzymes in MCF10A cells. Whether such modulation leads to any potential benefit in estrogen metabolism and carcinogenesis needs to be addressed in future studies of the effects of $\mathrm{As}_{2} \mathrm{O}_{3}$ and resveratrol on estrogen metabolism.

\section{EXPERIMENTAL PROCEDURES}

Cytotoxicity. Cells were seeded in a 96-well plate (seeding density: MCF10A 3000 cells per well, MCF12F 5000 cells per well) in estrogen- and phenol-red-indicator-free media and treated with $0.5-50 \mu \mathrm{M}$ total concentration of $\mathrm{As}_{2} \mathrm{O}_{3}$ (purity > 99.5\%; Sigma-Aldrich, St. Louis, MO), 12.5-200 $\mu \mathrm{M}$ total concentration of resveratrol (purity $\geq 98 \%$; Cayman Chemical, Ann Arbor, MI), or 0.5-50 $\mu \mathrm{M}$ total concentration of $\mathrm{As}_{2} \mathrm{O}_{3}+$ $25 \mu \mathrm{M}$ resveratrol for two time points (48 and $72 \mathrm{~h}$ ). Finally, MTT (Calbiochem, San Diego, CA) was used to assess the cell viability.

Protein Expression Studies. Expression levels of the key estrogen-metabolizing enzymes NQO1 and CYP1B1 and of cell signaling protein $\mathrm{Nrf} 2$ were studied under different treatment regimens. Cells were seeded in a 6-well plate (seeding density: MCF10A and MCF10F $0.8 \times 10^{6}$ cells per well, MCF12F $1 \times$ $10^{6}$ cells per well) in estrogen- and phenol-red-indicator-free media and treated with $0.5-5 \mu \mathrm{M}$ total concentration of $\mathrm{As}_{2} \mathrm{O}_{3}$ $\pm 25 \mu \mathrm{M}$ resveratrol for $48 \mathrm{~h}$. Following cell lysis with radioimmunoprecipitation assay buffer containing protease inhibitor cocktail (Roche Diagnostics, Basel, Switzerland), total protein was estimated by the Bradford assay, and 10-30 $\mu \mathrm{g}$ of total protein was resolved on a $15 \%$ polyacrylamide gel and transferred to poly(vinylidene difluoride) membranes. The membranes were probed with anti-NQO1, anti-Nrf2 (Abcam, Cambridge, MA), anti-CYP1B1 (LSBio, Seattle, WA), or anti$\beta$-actin (Santa Cruz, Dallas, TX) primary antibodies overnight at $4{ }^{\circ} \mathrm{C}$ and secondary antibodies for $1 \mathrm{~h}$ at room temperature. Detection was performed with ECL Western Blotting Detection Reagents (GE Healthcare/Amersham, Little Chalfont, U.K.). Both the treatment and western blotting were performed three times to achieve statistical significance.

Statistical Analysis. To determine whether the differences observed were statistically significant, a 2 -sample $t$-test was performed. $\alpha$ was set at 0.05 for all statistical tests, and data with $p<0.05$ were considered to be significantly different. 


\section{ASSOCIATED CONTENT}

\section{S Supporting Information}

The Supporting Information is available free of charge on the ACS Publications website at DOI: 10.1021/acsomega.7b01727.

The expression of CYP1B1 by $\mathrm{As}_{2} \mathrm{O}_{3}$ with and without resveratrol in MCF10A, MCF10F, and MCF12F cells; the viability of MCF12F cells treated with $\mathrm{As}_{2} \mathrm{O}_{3}$ (PDF)

\section{AUTHOR INFORMATION}

\section{Corresponding Author}

*E-mail: mzahid@unmc.edu. Phone: 1-402-559-8912. Fax: 1402-559-7259.

\section{ORCID}

Muhammad Zahid: 0000-0002-9975-9476

\section{Author Contributions}

The manuscript was written through contributions of all authors.

\section{Funding}

This project was supported by an internal grant of the University of Nebraska Medical Center, awarded and administered by the College of Public Health, UNMC, Omaha, NE. Core support at the Eppley Institute was provided by grant P30 CA36727 from the National Cancer Institute at the National Institutes of Health.

\section{Notes}

The authors declare no competing financial interest.

\section{ACKNOWLEDGMENTS}

We thank Drs. Rizwan Ahmed and Amar B. Singh for their assistance with cell counting and densitometry of Western Blots.

\section{ABBREVIATIONS}

$\mathrm{As}_{2} \mathrm{O}_{3}$, arsenic trioxide; NQO1, NAD $(\mathrm{P}) \mathrm{H}$ quinone dehydrogenase 1; Nrf2, NFE2-related factor 2; CYP1B1, cytochrome P450 1B1; CYP19, cytochrome P450 19; COMT, catechol-Omethyltransferase; $\mathrm{E}_{2}$, estradiol; 4- $\mathrm{OHE}_{2}$, 4-hydroxyestradiol; $\mathrm{E}_{2}$-3,4-Q, estradiol-3,4-quinone; TCDD, 2,3,7,8-tetrachlorodibenzo-p-dioxin

\section{REFERENCES}

(1) Saha, J. C.; Dikshit, A. K.; Bandyopadhyay, M.; Saha, K. C. A review of arsenic poisoning and its effects on human health. Crit. Rev. Environ. Sci. Technol. 1999, 29, 281-313.

(2) Straif, K.; Benbrahim-Tallaa, L.; Baan, R.; Grosse, Y.; Secretan, B.; El Ghissassi, F.; Bouvard, V.; Guha, N.; Freeman, C.; Galichet, L.; Cogliano, V. A review of human carcinogens-part C: metals, arsenic, dusts, and fibres. Lancet Oncol. 2009, 10, 453-454.

(3) Soignet, S. L.; Maslak, P.; Wang, Z. G.; Jhanwar, S.; Calleja, E.; Dardashti, L. J.; Corso, D.; DeBlasio, A.; Gabrilove, J.; Scheinberg, D. A.; Pandolfi, P. P. Complete remission after treatment of acute promyelocytic leukemia with arsenic trioxide. N. Engl. J. Med. 1998, 339, 1341-1348.

(4) Bodwell, J. E.; Gosse, J. A.; Nomikos, A. P.; Hamilton, J. W. Arsenic disruption of steroid receptor gene activation: complex dose response effects are shared by several steroid receptors. Chem. Res. Toxicol. 2006, 19, 1619-1629.

(5) United States Environmental Protection AgencyOffice of Water (4607) The Technical Fact Sheet: Final Rule for Arsenic in Drinking Water; 815-F-00-016; EPA, 2001.

(6) Chen, C.; Jiang, X.; Lai, Y.; Liu, Y.; Zhang, Z. Resveratrol protects against arsenic trioxide-induced oxidative damage through main- tenance of glutathione homeostasis and inhibition of apoptotic progression. Environ. Mol. Mutagen. 2015, 56, 333-346.

(7) Zhang, W.; Guo, C.; Gao, R.; Ge, M.; Zhu, Y.; Zhang, Z. The protective role of resveratrol against arsenic trioxide-induced cardiotoxicity. J. Evidence-Based Complementary Altern. Med. 2013, 2013, 1-8.

(8) Zhang, W.; Liu, Y.; Ge, M.; Jing, J.; Chen, Y.; Jiang, H.; Yu, H.; Li, N.; Zhang, Z. Protective effect of resveratrol on arsenic trioxideinduced nephrotoxicity in rats. Nutr. Res. Pract. 2014, 8, 220-226.

(9) Zhang, Z.; Gao, L.; Cheng, Y.; Jiang, J.; Chen, Y.; Jiang, H.; Yu, H.; Shan, A.; Cheng, B. Resveratrol, a natural antioxidant, has a protective effect on liver injury induced by inorganic arsenic exposure. BioMed Res. Int. 2014, 2014, $1-7$.

(10) Tokar, E. J.; Diwan, B. A.; Waalkes, M. P. Arsenic exposure transforms human epithelial stem/progenitor cells into a cancer stemlike phenotype. Environ. Health Perspect. 2010, 118, 108.

(11) Achanzar, W. E.; Brambila, E. M.; Diwan, B. A.; Webber, M. M.; Waalkes, M. P. Inorganic arsenite-induced malignant transformation of human prostate epithelial cells. J. Natl. Cancer Inst. 2002, 94, 18881891.

(12) Xu, Y.; Tokar, E. J.; Waalkes, M. P. Arsenic-induced cancer cell phenotype in human breast epithelia is estrogen receptor-independent but involves aromatase activation. Arch. Toxicol. 2014, 88, 263-274.

(13) Yue, W.; Wang, J. P.; Li, Y.; Bocchinfuso, W. P.; Korach, K. S.; Devanesan, P. D.; Rogan, E.; Cavalieri, E.; Santen, R. J. Tamoxifen versus aromatase inhibitors for breast cancer prevention. Clin. Cancer Res. 2005, 11, 925s-930s.

(14) Russo, J.; Lareef, M. H.; Balogh, G.; Guo, S.; Russo, I. H. Estrogen and its metabolites are carcinogenic agents in human breast epithelial cells. J. Steroid Biochem. Mol. Biol. 2003, 87, 1-25.

(15) Cavalieri, E.; Rogan, E. The molecular etiology and prevention of estrogen-initiated cancers: Ockham's Razor: Pluralitas non est ponenda sine necessitate. Plurality should not be posited without necessity. Mol. Aspects Med. 2014, 36, 1-55.

(16) Zahid, M.; Gaikwad, N. W.; Ali, M. F.; Lu, F.; Saeed, M.; Yang, L.; Rogan, E. G.; Cavalieri, E. L. Prevention of estrogen-DNA adduct formation in MCF-10F cells by resveratrol. Free Radical Biol. Med. 2008, 45, 136-145.

(17) Ungvari, Z.; Bagi, Z.; Feher, A.; Recchia, F. A.; Sonntag, W. E.; Pearson, K.; De Cabo, R; Csiszar, A. Resveratrol confers endothelial protection via activation of the antioxidant transcription factor $\mathrm{Nrf} 2$. Am. J. Physiol. 2010, 299, H18-H24.

(18) He, X.; Chen, M. G.; Lin, G. X.; Ma, Q. Arsenic induces $\mathrm{NAD}(\mathrm{P}) \mathrm{H}$-quinone oxidoreductase I by disrupting the Nrf2 Keap1 Cul3 complex and recruiting Nrf2. Maf to the antioxidant response element enhancer. J. Biol. Chem. 2006, 281, 23620-23631.

(19) Itoh, K.; Wakabayashi, N.; Katoh, Y.; Ishii, T.; O'connor, T.; Yamamoto, M. Keap1 regulates both cytoplasmic-nuclear shuttling and degradation of Nrf2 in response to electrophiles. Genes Cells 2003, 8, 379-391.

(20) Li, S. G.; Xu, S. Z.; Niu, Q.; Ding, Y. S.; Pang, L. J.; Ma, R. L.; Jing, M. X.; Wang, K.; Ma, X. M.; Feng, G. L.; Liu, J. M.; et al. Lutein alleviates arsenic-induced reproductive toxicity in male mice via $\mathrm{Nrf} 2$ signaling. Hum. Exp. Toxicol. 2016, 35, 491-500.

(21) Spink, D. C.; Spink, B. C.; Cao, J. Q.; DePasquale, J. A.; Pentecost, B. T.; Fasco, M. J.; Li, Y.; Sutter, T. R. Differential expression of CYP1A1 and CYP1B1 in human breast epithelial cells and breast tumor cells. Carcinogenesis 1998, 19, 291-298.

(22) Anwar-Mohamed, A.; El-Sherbeni, A. A.; Kim, S. H.; Althurwi, H. N.; Zordoky, B. N.; El-Kadi, A. O. Acute arsenic toxicity alters cytochrome $\mathrm{P} 450$ and soluble epoxide hydrolase and their associated arachidonic acid metabolism in $\mathrm{C} 57 \mathrm{Bl} / 6$ mouse heart. Xenobiotica 2012, 42, 1235-1247.

(23) Lu, F.; Zahid, M.; Wang, C.; Saeed, M.; Cavalieri, E. L.; Rogan, E. G. Resveratrol prevents estrogen-DNA adduct formation and neoplastic transformation in MCF-10F cells. Cancer Prev. Res. 2008, 1, $135-145$. 